\title{
The antiquity of cranial surgery in Europe and in the Mediterranean basin
}

\author{
Éric Crubézy ${ }^{\mathrm{a}, *}$, Jaroslav Bruzek $^{\mathrm{b}}$, Jean Guilaine ${ }^{\mathrm{c}}$, Eugenia Cunha $^{\mathrm{d}}$, Daniel Rougé $^{\mathrm{a}}$, Jan Jelinek $^{\mathrm{e}}$ \\ a UMR 8555 du CNRS, université Paul-Sabatier (Toulouse), 39, allées Jules-Guesde, 31000 Toulouse, France \\ b UMR 5809 du CNRS, université Bordeaux-1, avenue des Facultés, 33405 Talence, France \\ c UMR 85555 du CNRS et Collège de France, Paris, France \\ d Departamento de Antropologia, Faculdade de Ciências e Tecnologia, Universidade de Coimbra, 3000-056 Coimbra, Portugal \\ e Anthropos Institute, Moravian Museum, Zelny trh 6, 65937 Brno, Czech Republic
}

Received 5 June 2000; accepted 12 February 2001

Communicated by Yves Coppens

\begin{abstract}
Through personal observations and a literature study we have made a synthesis of the most ancient healed trephinations in Europe and in the Mediterranean basin. Cases of small dimensions that were carried out with simple techniques are found in the Mesolithic populations from North Africa, Ukraine and Portugal. The first Neolithic examples of trephinations are extensive and have been realised with more sophisticated techniques. This suggests that the development of agriculture was accompanied by the command of new procedures in the field of surgery. @ 2001 Académie des sciences / Éditions scientifiques et médicales Elsevier SAS
\end{abstract}

\section{trephination / Neolithic / Mesolithic / North Africa / Ukraine / Portugal / Europa}

\begin{abstract}
Résumé - Ancienneté de la chirurgie crânienne en Europe et dans le Bassin méditerranéen. À partir d'observations et de la littérature, nous avons effectué une synthèse des plus anciennes trépanations cicatrisées en Europe et dans le Bassin méditerranéen. Des cas de trépanations de petites dimensions et réalisées avec des techniques simples sont retrouvés dans les populations mésolithiques de l'Afrique du Nord, de l'Ukraine et du Portugal. Les premiers exemples néolithiques sont de vastes dimensions, réalisés avec des techniques plus complexes. Cela suggère que le développement de l'agriculture s'est accompagné très tôt d'une maîtrise de gestes nouveaux dans le domaine chirurgical. @ 2001 Académie des sciences / Éditions scientifiques et médicales Elsevier SAS
\end{abstract}

trépanations / Néolithique / Mésolithique / Afrique du Nord / Ukraine / Portugal / Europe

\section{Version abrégée}

\section{Introduction}

Les trépanations préhistoriques, reconnues depuis la fin du $19^{\mathrm{e}}$ siècle [8], ont été retrouvées dans de nombreuses régions du monde. En Europe et dans le Bassin méditerranéen, la majorité d'entre elles est attribuable à la fin du Néolithique et/ou au début de l'âge du Bronze. Bien que certaines soient datées du $\mathrm{V}^{\mathrm{e}}$ et au $\mathrm{IV}^{\mathrm{e}}$ millénaire $\mathrm{BC}$, les origines de cette pratique restent inconnues. Ces dernières années, plusieurs cas de trépanation ont été signalés parmi les premières cultures néolithiques de l'Europe, tant dans le courant danubien que méditerranéen, mais aussi dans le Mésolithique de l'Ukraine.

\section{Matériel et méthodes}

Afin d'étudier les origines et la diffusion de cette pratique, nous avons sélectionné les crânes présentant des

\footnotetext{
${ }^{*}$ Correspondence and reprints.

E-mail address: crubezyeric@wanadoo.fr (É. Crubézy).
} 
signes incontestés de trépanation ou de grattage ou de trépanation incomplète provenant de sites dont les attributions culturelles et la datation sont clairement définies ou ont été récemment revues. Les crânes du site de Concheiro da Moita do Sebastião (Portugal) ont été examinés pour la première fois dans cette optique et plusieurs crânes ont été étudiés par les auteurs; d'autres avaient été soigneusement décrits, bien que, pour les trépanations incomplètes, la prudence restât de rigueur. Le crâne de Pendimoun a été inclus dans la mesure où les autres possibilités diagnostiques envisagées ne semblent pas pouvoir être retenues. Celui de Jéricho a été écarté, la datation étant mal assurée.

\section{Résultats}

\subsection{Les cas mésolithiques}

Quatre cas datés d'environ 10000 BP ont été recensés : en Afrique du Nord (Taforalt), en Ukraine Vasiliyevka II, $\mathrm{n}^{\circ}$ 6462-20, Vasiliyevka II, $\mathrm{n}^{\circ}$ 6285-9, et Vovnigi II, $\mathrm{n}^{\circ}$ 54. Par ailleurs, aux même dates, en Afrique du Nord, quatre cas d'abrasion ou de trépanations incomplètes ont été signalées. Un peu plus tardive, 6000 BC environ, est la trépanation incomplète de Concheiro da Moita do Sebastião ( $\mathrm{n}^{\circ}$ XLI) à Muge au Portugal. Un cas de grattage a été signalé dans une population en cours de sédentarisation à Zawi Chemi (Shanidar, Iraq). Toutes ces trépanations sont de petites dimensions et ont été réalisées par grattage et/ou par perçage.

\subsection{Les plus vieux cas néolithiques}

Les plus anciens sont ceux de Vedrovice en Moravie (République tchèque) et de Pendimoun, sur la côte méditerranéenne, à la frontière franco-italienne. Vedrovice est l'un des plus anciens sites de la céramique linéaire et il présente d'étroites affinités mésolithiques. Le squelette de Pendimoun est attribué à une phase précoce du Néolithique ancien ouest-méditerranéen. Trois autres cas plus récents, celui de Ensisheim et ceux de Trasano et de la Grotta Patrizi sont sensiblement contemporains. Sur ces cinq crânes trépanés, quatre présentent deux orifices ; les trépanations sont vastes, elles sont toutes situées sur le trajet de sinus veineux, ce qui en fait des interventions à risque. Les techniques utilisées sont toujours complexes, avec toujours des incisions plus ou moins associées à des abrasions, ce qui fait que certaines controverses peuvent être considérées comme dépassées. À Vedrovice, la cause de la trépanation était un traumatisme très important et le choix des chirurgiens fut particulièrement judicieux sur cette intervention à risques.

\section{Discussion et conclusions}

Bien que la pratique de la trépanation soit absente de certaines séries importantes du Mésolithique et du Néolithique ancien, il est clair qu'elle existait déjà à ces périodes dans des endroits distants dans le temps et l'espace. Les cas mésolithiques sont de petites dimensions et ont été réalisés avec des techniques simples; les plus vieux cas néolithiques, tant du courant danubien que méditerranéen, sont de grandes dimensions et ont été réalisés avec des techniques à risque par des chirurgiens qui pouvaient faire preuve d'un grand professionnalisme. Dès lors, s'il est actuellement difficile d'affirmer que cette pratique a diffusé depuis le Moyen-Orient, on peut cependant supposer un fond chirurgical commun aux populations relevant des deux grands courants de néolithisation européen. Comme pour l'émergence de l'agriculture, l'hypothèse de liens étroits entre ces courants n'est donc pas à écarter, d'autant plus que ceux-ci divergent à partir d'un noyau commun en Europe du Sud-Est. Par ailleurs, cela suggère que le développement de l'agriculture, en plus de modifications des techniques dans les domaines de l'économie et de l'outillage, se soit aussi accompagné très tôt d'une maîtrise de gestes nouveaux dans le domaine chirurgical.

\section{Introduction}

Prehistoric cranial trephination was demonstrated at the end of the 19th century [8] and since then it has been found in numerous populations throughout the world [31, 39]. In Europe, and more generally in the Mediterranean basin, this practice has been recognized in hundreds of skulls $[5,9,11,12,21,33]$ dating from the Late Neolithic and Early Bronze Age (around $2300 \mathrm{BC}$ on the Mediterranean coast of western Europe). Also in Europe and in the Mediterranean basin, some examples can be attributed to the 5th and 4 th millennium BC $[3,5,7,15]$. However, the origin and development of trephination remain largely unclear and we do not know to what extent this practice, often considered as of magical and religious significance [4], was accompanied by genuine knowl- edge of the surgical treatment of patients. Recently, Alt et al. [1] described double trephination in an individual from the burial ground at Ensisheim, Alsace, France, dating from $5100 \mathrm{BC}$, which can be linked with the linear pottery culture, which represented one of the two major currents of Neolithic expansion in Europe [41]. These authors present this as the oldest known example in the world [25] and it bears witness to the high craftsmanship of the surgeon. Consequently, the question arises as to whether this practice was invented by people of the linear ceramic culture in western Europe or whether, on the contrary, it was much older. In fact, recent publications [6, $10,16]$, taking into account findings from incontrovertible sites which are adequately dated and welldocumented but which have been omitted by some researchers $[4,31]$, reveal the development of trephina- 
É. Crubézy et al. / C. R. Acad. Sci. Paris, Sciences de la Terre et des planètes / Earth and Planetary Sciences 332 (2001) 417-423

tion among the hunter-gatherers of North Africa [11] and Ukraine [17] and then its simultaneous expansion, in a highly skilled form, via the two main currents of the advance of Neolithic culture in Europe, the Mediterranean and Danubian currents, of which Ensisheim is merely one of the last outposts [25].

\section{Material and methods}

Trephination may be defined as the removal of a piece of the skull of a living individual without penetration of the underlying soft tissues [31]. We have only studied examples that had healed. Under the term of trephination, we have also taken into consideration surgical treatment with scraping and sawing of a multiple fracture of the cranial vault comprising a depressed fracture. The term of scraping or incomplete trephination is understood as healed abrasion of the vault, which did not reach the soft tissues. It should however be noted that in the case of scraping, the diagnosis is much more difficult to affirm than for sawing or drilling. Specially difficult is the differential diagnosis of cholesteatom or of an epidermoid cyst subcutaneous (for these problems see Thillaud 1983 [40]). Three types of operative procedures have been identified and analyzed [31]: scraping or abrasion, incision or sawing, and drilling. The other types of procedure mentioned in the literature and relating to more recent periods (boring and cutting, rectangular intersecting incisions) were not observed by us.

In order to study the origin and dissemination of cranial trephination, we selected skulls showing clear evidence of this procedure [27] or of scraping and incomplete trephination [6] and originating from sites which are adequately dated or whose cultural attributions are clearly defined [19]. The sample of Concheiro da Moita do Sebastião in Portugal, has been studied for the first time in this perspective and some other skulls have been studied by the authors of the present paper [10]. The pathological features of the samples from which these skulls originated have in some instances been dealt with in detailed publications $[10,11,14]$. Some of these skulls have been studied by the authors of the present paper [19]. Other sites, which have perhaps yielded equally ancient examples of trephination but which have not been so meticulously described, or whose cultural attribution remains doubtful, are not reviewed here [28]. The example of Pendimoun, France, has been taken into consideration inasmuch as the other diagnostic possibilities raised [6] cannot be endorsed. The cultural attributions of the sites have been reviewed in the light of recent work [19].

\section{Results}

\subsection{Mesolithic examples}

Several examples of trephination well before the Neolithic period are known in populations of Epipaleolithic and Mesolithic hunter-gatherers (figure 1). One of these at Taforalt (figure 2) in North Africa shows healed trephination [11], as does another in eastern Europe at Vasiliyevka III (figure 3), No. 646220 [17], in the Dnieper rapids region of Ukraine. These examples all date from around the same era, about 10000 BP. The other undoubted examples of trephination, those of Vasiliyevka II, No. 6285-9 [17] and of Vovnigi II, No. 54 [17] from the Ukraine, have recently been cited [29]. In addition, at Taforalt there was one example of abrasion and another skull had undergone partial trephination, which did not penetrate to the inner table of the skull. Two more examples are known at another site, which is close both in time and space, Afalou-bou-Rhumel [13]. However, in some cases we must be very careful for the attribution according to the fact that some diagnosis of partial trephination made by J. Dastugue on others sites have sometimes be discussed [40]. We have found one other Mesolithic example of partial trephination which seems to have been made by drilling in the large Mesolithic sample of Concheiro da Moita do Sebastião (skull XLI) in Muge, Portugal (figure 4) around 6000 BC [22]. Somewhat other examples of scraping are known in the Middle East at Zawi Chemi, Shanidar, Iraq [14], where there are early signs of a settled population. These examples of trephination prior to the Neolithic period are of very small dimensions and, like incomplete trephination, they were carried out with drilling and/or abrasion techniques.

\subsection{Early Neolithic examples}

The oldest examples are those, all dating from around the same era, which are linked with the Danubian current (of which Ensisheim and the other skulls from the French sites of the linear ceramic culture merely represent the westernmost outpost) with other examples from the Mediterranean axis. Among these ancient examples may be mentioned those of Vedrovice in Moravia, Czech Republic [10] and Pendimoun on the Mediterranean coast in France [6]. Vedrovice is one of the oldest sites of the linear pottery culture [36] and it still shows close affinities with the Mesolithic period [26]. The skeleton from Pendimoun can be attributed to an early phase of the early western Mediterranean Neolithic period. At Vedrovice, trephination was done after an open cranial injury, which had fractured and sunk the bone in at least two places. The prehistoric surgeons had demarcated an extensive area between the two large fragments and they 


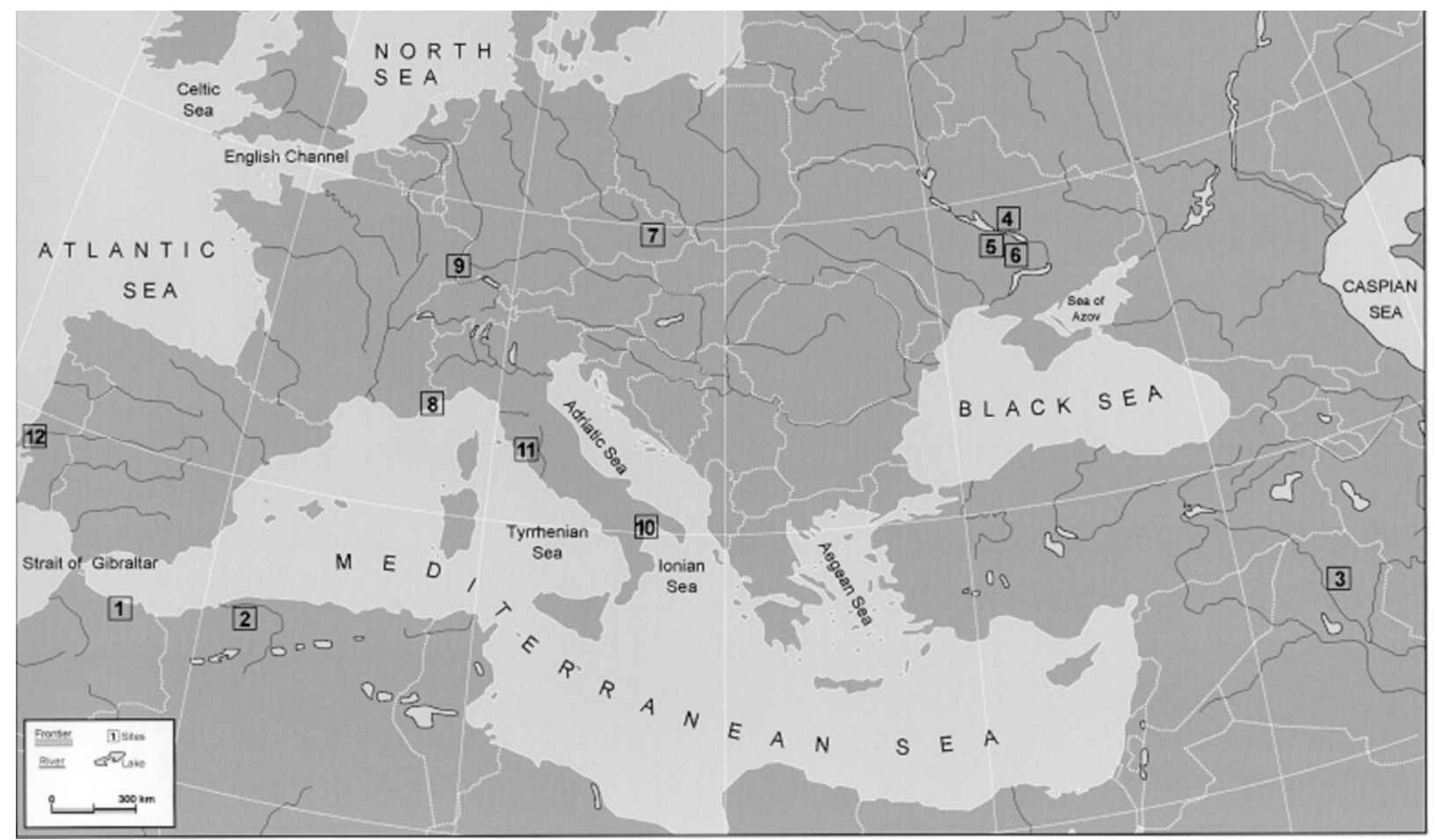

Figure 1. Geographical distribution of the trephination sites: 1, Taforalt, Morocco [11]; 2, Afalou-bou-Rhummel, Algeria [13]; 3, Zawi Chemi, Irak [14]; 4, Vasilyevka III, Ukraine [17]; 5, Vasilyevka II, Ukraine [17]; 6, Vovnigi Iin, Ukraine [18]; 7, Vedrovice, Czech Republic [10]; 8, Pendimoun, France [6]; 9, Ensisheim, France [1]; 10, Trasano, Italy [16]; 11, Grotta Patrizi, Italy [16]; 12, Concheiro da Moita do Sebastião, Muge, Portugal. Cultural attributions and datations: 1, Taforalt, Epipaleolithic, $11900 \pm 240 \mathrm{BP}$ [37, 38]; 2, Afalou-bou-Rhumel, Epipaleolithic [13]; 3, Zawi-Chemi, $10870 \pm 300$ BP [14]; 4, Vasilyevka III, Epipaleolithic, 10000 BP [23, 24]; 5, Vasilyevka II, Late Mesolithic, 8020-7620 BP [30]; 6, Vovnigi II, Dnieper-Donec Neolithic culture, 5470-4783 BC [30]; 7, Vedrovice, ancient Danubian, LnK [26, 36]; 8, Pendimoun, ancient Mediterranean Neolithic, 5570-5270 BC [6]; 9, Ensisheim, LnK, $6155 \pm 39$ BP [1]; 10, Trasano, Neolithic culture from Passo di Corvo-Catignano; ten datations from $6330 \pm 70$ to $5910 \pm 65 \mathrm{BP}$, around $5000 \mathrm{BC}$ [16]; 11, Grotta Patrizi, Neolithic culture from Sasso, transition VIth-Vth millenium BC [16]; 12. Concheiro da Moita do Sebastião, Muge, Portugal, Mesolithic around 6000 BC [22].

Figure 1. Distribution géographique des trépanations; sites : 1, Taforalt, Maroc [11]; 2, Afalou-bou-Rhummel, Algérie [13]; 3, Zawi Chemi, Irak, [14] ; 4, Vasilyevka III, Ukraine [17] ; 5, Vasilyevka II, Ukraine [17]; 6, Vovnigi II, Ukraine [18] ; 7, Vedrovice, République tchèque [10]; 8, Pendimoun France [6]; 9, Ensisheim, France [1]; 10, Trasano, Italie [16]; 11, Grotta Patrizi, Italie [16]; 12, Concheiro da Moita do Sebastião, Muge, Portugal. Attributions culturelles et datations : 1, Taforalt, Épipaléolithique, $11900 \pm 240$ BP [37, 38] ; 2, Afalou-bou-Rhumel, Épipaléolithique [13] ; 3, Zawi-Chemi, $10870 \pm 300$ BP [14] ; 4, Vasilyevka III, Épipaléolithique, 10000 BP [23, 24] ; 5, Vasilyevka II, Mésolithique final, 8020-7620 BP [30]; 6, Vovnigi II, Néolithique de la culture Dnieper-Donec, 5470-4783 BC [30]; 7, Vedrovice, phase ancienne du Danubien $[26,36] ; \mathbf{8}$, Pendimoun, Néolithique ancien méditerranéen, 5570-5270 BC [6]; 9, Ensisheim, LnK, $6155 \pm 39$ BP [1] ; 10, Trasano, culture néolithique de Passo di Corvo-Catignano; dix datations de $6330 \pm 70$ to $5910 \pm 65$ BP, soit aux alentours de 5000 BC [16]; 11, Grotta Patrizi, culture néolithique de Sasso, charnière $\mathrm{VI}^{\mathrm{e}}-\mathrm{V}^{\mathrm{e}}$ millénaire $\mathrm{BC}[16]$; 12, Concheiro da Moita do Sebastiao, Muge, Portugal, Mésolithique, aux alentours de $6000 \mathrm{BC}[22]$.

cautiously proceeded with scraping. Once the lesions were well surrounded, the intervention was finally demarcated and adapted (bevel or vertical regularisation). This was a risky procedure where what counted first and foremost was the rapidity of the intervention and keeping damage to a minimum. The examples from Ensisheim [1], Trasano and the Grotta Patrizi, more recent, date from around the same period [16].

In these five examples from the Early Neolithic period, the trephinations are extensive. They are all located on the course of the venous sinus and were thus risky procedures. The techniques that were used often seem complex, always comprising incision and vary- ing degrees of abrasion. Of the trephinations mentioned, Vedrovice is the only one that has a known cause. Another skull from the European Middle Neolithic period [16], No. 92 from Catignano, Pescara, Italy, belonging to the same cultural group as that of Trasano, shows signs of a surgical procedure, without trephination, after injury. Pendimoun and Ensisheim have both yielded an example of two extensive trephinations on a single skull, and on the skeleton from the Grotta Patrizi a second trephination was attempted but shows no sign of healing. In fact, four out of five skulls with trephination have two orifices. In the skull with a single orifice (Trasano), it seems that the bone 

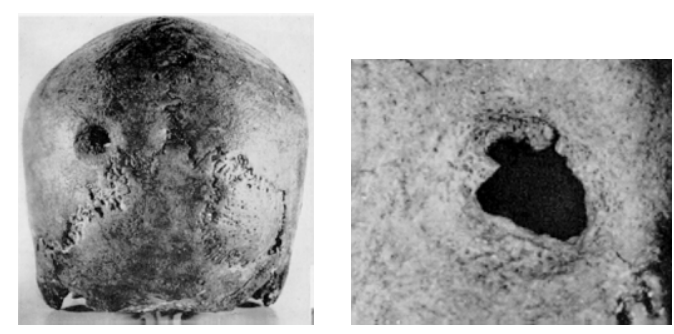

Figure 2. Taforalt Ia. Aperture of oval form $(10.5 \times 8.5 \mathrm{~mm})$ on the left parietal, at $45 \mathrm{~mm}$ from the lambda with a chamfered edge at the expense of the external table with healing. The radiograph confirms the absence of lesion of the internal table. These observations confirm the trephination and the surviving of the subject. 1. General view. 2. Detailed view. Photograph from Dastugue [11].

Figure 2. Taforalt Ia. Orifice de forme ovalaire $(10,5 \times 8,5 \mathrm{~mm})$ siégant sur le pariétal gauche, à $45 \mathrm{~mm}$ en dehors du lambda, avec un pourtour taillé en biseau aux dépens de la table externe. Les parois sont faites d'os néoformé. Ces constatations, jointes à l'absence de lésion de la table interne, confirmées par la radiographie, témoignent de la trépanation. 1. Vue d'ensemble. 2. Vue de détail. Photo : d'après Dastugue [11].

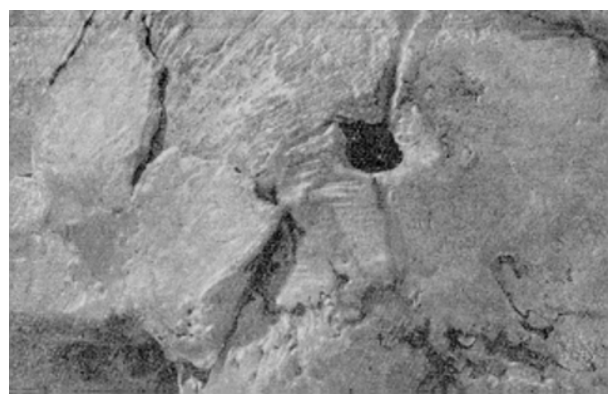

Figure 3. Epipaleolithic case from Vasiliyevka III grave 31, No. of the catalogue MAE 6462-18, from Goikhman 1966 [17]. Orifice of oval and conic form on the left parietal, around $17 \mathrm{~mm}$ from the parieto-mastoidian suture. Dimensions $16 \times 18 \mathrm{~mm}$ at the external part and only $8.2 \times 9.3 \mathrm{~mm}$ at the internal part. Photograph from Goikhman [17].

Figure 3. Cas épi-paléolithique, de Vasiliyevka III, sépulture 31, $\mathrm{n}^{\circ}$ du catalogue MAE 6462-18, selon Goikhman 1966 [17]. Orifice ovalaire et conique qui mesure $16 \times 18 \mathrm{~mm}$ de côté externe et seulement $8,2 \times 9,3 \mathrm{~mm}$ de côté interne, localisé sur le pariétal gauche; il est situé à environ $17 \mathrm{~mm}$ au-dessus de la suture pariétomastoïdienne. Photo : Goikhman [20].

flap that was removed was replaced in order to cover the access to the hole. This has recently fuelled a controversy $[32,35]$. One of the arguments of those who (mistakenly) reject this trephination is that 'trepanation at the bregma would in all likelihood be lethal in that the patient would quickly succumb to bleeding to the sagittal sinus' [35]. In fact, all the other examples demonstrate on the contrary that even as far back as the Early Neolithic period, cranial surgeons had reached a high level of competence, including in their operative choices!
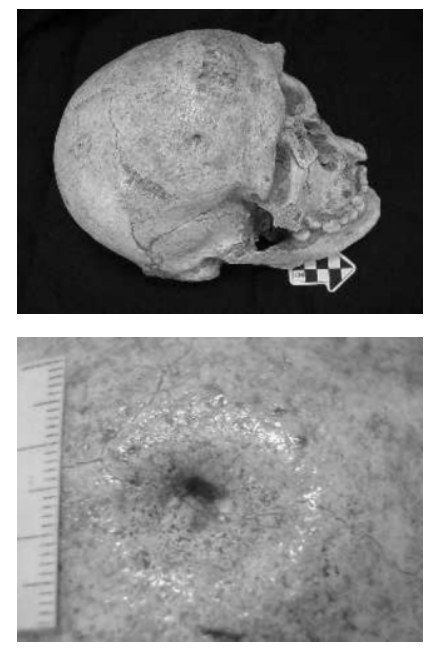

Figure 4. Concheiro da Moita do Sebastião, Muge, Portugal. Skull of an adult man with part of soil in it. It has been varnished after its discovery. At the lateral part of the right frontal relief, irregular area with a conic healed depression from $13 \mathrm{~mm}$ antero-posterior to $17 \mathrm{~mm}$ latero-medial of major diameter and around $10 \mathrm{~mm}$ of depth. It does not seem that it penetrates to the inner part of the skull. It is healed with traces of periosteal reaction not active at the moment of the death. The conic depression is the result of a drilling that has been realised from the lateral to the medial part on an area, may be a traumatic one because it is irregular, which could have been scrapped before the drilling. 1. General view. 2. Detailed view.

Figure 4. Concheiro da Moita do Sebastião, Muge, Portugal. Homme, adulte. Le crâne, avec encore du sédiment à l'intérieur, a été verni anciennement. À la partie latérale de la bosse frontale droite, zone irrégulière, avec une dépression conique de $13 \mathrm{~mm}$ de diamètre antéro-postérieur à $17 \mathrm{~mm}$ de diamètre latéro-médial et de presque $10 \mathrm{~mm}$ de profondeur. Elle ne pénètre apparemment pas dans l'endocrâne. Elle est cicatrisée, avec des traces de réactions périostées en phase non active. La dépression résulte d'un perçage réalisé de la partie latérale vers la partie médiale et certainement précédé d'un grattage sur une zone qui avait peut-être subi un traumatisme irrégulier. 1. Vue d'ensemble. 2. Vue de détail.

\section{Discussion}

The practice of trephination appears in several Mesolithic sites and is clearly present in the Early Neolithic period in central Europe and the western Mediterranean. However trephination is absent is absent from samples of Mesolithic skeletons from the Iron Gates [34] and of the first large series of Neolithic skeletons, those of Catal Hüyük in Turkey [2] and of Cyprus, although it may have been known in Jericho from the 10th millennium.

\section{Conclusions}

The oldest examples of trephination (Mesolithic) are small in size; they appear in populations of huntergatherers distant from one another in time and in space (North Africa, Ukraine, Portugal) and their small area together with the very simple techniques 
É. Crubézy et al. / C. R. Acad. Sci. Paris, Sciences de la Terre et des planètes / Earth and Planetary Sciences 332 (2001) 417-423

used (drilling and/or abrasion) [9] could argue for autonomous, unrelated centres. At the beginning of $\mathrm{Ne}$ olithic the cases are large and the practice trephination shows a high degree of skill, implying that there was already a long tradition of surgical experience. For example, in the Danubian culture, at Vedrovice, the surgeons gave proof of great professionalism. Their intervention was technically perfect and it is obvious that they would have been able to carry out an extensive skull trephination like the two in the Pendimoun skull $(76.1 \times 43 \mathrm{~mm}$ and $73.5 \times 66.2 \mathrm{~mm})$ in the Mediterranean culture. However, in such a context of emergency, there was a likelihood that the patient would die, so the procedure was adapted to the condition of the patient. So, we may suppose there was a common fund of surgical knowledge in the populations belonging to the two main currents of Neolithic expansion in Europe. As with the emergence of agriculture [20], the hypothesis of close links between these currents cannot be ruled out, especially as they diverge from a common nucleus in south-eastern Europe. In addition, this suggests that the development of agriculture was accompanied not only by changes in techniques relating to implements and the economy but also, very early on, by the command of new procedures in the field of surgery.

Acknowledgement. The authors are grateful to T. Mollesson and to J. Person from the British Museum Natural History for the information about the sample of Catal-Hüyük, to Dr J. Brandão from the Museum dos Serviços Geológicos (Lisbon) for permitting the study of the skull of Concheiro da Moita do Sebastião, and to M. Serin and to J. Catalaa from the Laboratoire d'anthropologie de l'université de Bordeaux-1 for the map.

\section{References}

[1] Alt K.W., Jeunesse C., Buitrago-Téllez C.H., Wächter R., Boës E., Pichler S.L., Evidence for stone age cranial surgery, Nature 387 (1997) 360.

[2] Angel J.L., Early Neolithic skeletons from Çatal Hüyük: demography and pathology, Anatolian Studies XXI (1971) 77-98.

[3] Arensburg B., Hershkovitz I., Cranial deformation and trephination in the Middle East, Bull. Mém. Soc. Anthrop. de Paris 5 (3) (1988) 139-150.

[4] Aufderheide A.C., The enigma of Ancient cranial trepanation, Minnesota Medicine 68 (2) (1985) 119-122.

[5] Bennike P., Palaeoanthropology of danish skeletons, Akademisk Forlag, Copenhagen, Denmark.

[6] Binder D., Brocher J.-E., Duday H., Helmer D., Marinval P., Thiébault S., Wattez J., L'abri Pendimoun à Castellar, Alpes-Maritimes : nouvelles données sur le complexe culturel de la céramique imprimée méditerranéenne dans son contexte stratigraphique, Gallia Préhistoire 35 (1993) 177-251.

[7] Boutin J.-Y., André D., Les Baumes-Chaudes et les trépanations crâniennes dans les Grands-Causes, Imprimerie Causses et Cévennes, Milhau, France, 1995.

[8] Broca P., Sur les trépanations préhistoriques, Bull. Mém. Soc. Anthrop. Paris, 2e série 11 (1876) 236-256.

[9] Campillo D., Neurosurgical pathology in prehistory, Acta Neurochirurgica 70 (1984) 275-290.

[10] Crubézy E., Surgery at the origins of agriculture: the case of central Europe, Anthropologie Brno XXXIV (3) (1996) 329-332.

[11] Dastugue J., Paléopathologie, in: Ferembach D. (Ed.), La nécropole épipaléolithique de Taforalt, Maroc oriental, Éditions du CNRS, Paris, 1962, pp. 133-158.

[12] Dastugue J., Crânes protohistoriques trépanés ou pathologiques d'Afrique du Nord, L'Anthropologie 77 (1-2) (1973) 63-92.

[13] Dastugue J., Pathologie des hommes épipaléolithiques d'Afalou-bou-Rhummel, Algérie, L'Anthropologie 79 (3) (1975) 483-506.

[14] Ferembach D., Étude anthropologique des ossements humains proto-néolithiques de Zawi Chemi Shanidar Irak, Sumer 26 (12) (1970) 21-65.
[15] Ferembach D., À propos d'une trépanation sur un fragment d'occipital humain Chalcolithique trouvé à Azor Israël, Serie Antropologica Garcia de Orta, Lisboa 1 (2) (1984) 139-142.

[16] Germanà F., Fornaciari G., Trapanazioni, craniotomie e traumi cranici in Italia dalla Preistoria all' Età moderna, Edizioni Giardini, Pisa, 1992.

[17] Goikhman V.A., O trepanatchii tcherepa v epochov mezolitika, Voprosy antropologii 23 (1966) 111-118.

[18] Gokhman I.I., in: Naselenie Ukrainy v epokhu mezolita i neolita: antropologitscheskiy ocherk, Editions Nauka, Moscow, 1966, pp. 1-197.

[19] Guilaine J., La mer partagée. La Mediterranée avant l'écriture 7000-2000 av. J.-C., Éditions Hachette, Paris, 1994.

[20] Guilaine J., Civilisation de 1'Europe au Néolithique et à l'âge du Bronze, Annuaire du Collège de France, Paris, 1996-1997, pp. 697-719.

[21] Hershkovitz I., Trephination: the earliest case in the Middle East, Mitekufat Haeven 20 (1987) 128-135.

[22] Jackes M., Lubell D., Meiklejohn C., Healthy but mortal: human biology and the first farmers of western Europe, Antiquity 71 (1997) 639-658.

[23] Jacobs K., Human postcranial variation in the Ukrainian Mesolithic-Neolithic, Curr. Anthropol. 34 (1993) 417-430.

[24] Jacobs K., Reply to Anthony 'On subsistence change at the Mesolithic-Neolithic transition', Curr. Anthropol. 35 (1994) 52-59.

[25] Jeunesse C., L'Archéologue 29 (1997) 35-37.

[26] Jeunesse C., Pratiques funéraires et sociétés danubiennes, in: Guilaine J. (Ed.), Sépultures d'Occident et genèse des mégalithismes 9000-3500 avant notre ère, Éditions Errance, 1998, pp. 41-58.

[27] Kaufman M.H., Whitaker D., McTavish J., Differential diagnosis of holes in the calvarium: application of modern clinical data to paleopathology, J. Archaeol. Sci. 24 (1997) 193-218.

[28] Kurth G., Roher-Ertl O., On the anthropology of the Mesolithic to Chalcolithic human remains from the Tell es-Sultan, in: Kenyon K.M. (Ed.), Jericho. Jordan in Excavations at Jericho, Editions British School of Archaeology, Jerusalem, 1981, pp. 407-499.

[29] Lillie M.C., Cranial surgery dates back to Mesolithic, Nature 391 (1998) 853-854. 
É. Crubézy et al. / C. R. Acad. Sci. Paris, Sciences de la Terre et des planètes / Earth and Planetary Sciences 332 (2001) 417-423

[30] Lillie M.C., The Mesolithic-Neolithic transition in Ukraine: new radiocarbon determinations for the cemeteries of the Dnieper Rapids Region, Antiquity 72 (1998) 184-188.

[31] Lisowski F.P., Prehistoric and early historic trepanation, in: Brothwell D., Sandison A. (Eds.), Diseases in Antiquity, Ch. C. Thomas Publ., Springfield, 1967, pp. 651-672.

[32] Mallegni F., Bertoldi F., Reply to the 'Comments on Mallegni and Valassina's secondary bone changes to a cranium discovered at Trasano, South Italy', J. Osteoarchaeol. 7 (1997) 558-559.

[33] Massarotti M., Le origini della neurochirurgia nei documenti preistorici e protostorici, Minerva Neurochirurgica 14 (1) (1970) 5678 .

[34] Nemeskéri J., Lengyel I., Paleopathology, in: Garasanin M. (Ed.), Vlasac. A Mesolithic Settlement in the Iron Gates, Serbian Acad. Sci. Arts Monograph., Belgrade, DXII 5 (II) (1978) 231-247.

[35] Nova S.A., Knüsel C.J., Comment on Mallegni and Valassina's 'Secondary Bone Changes to a cranium trepanation in a Ne- olithic Man Discovered at Trasano, South Italy', Int. J. Osteoarchaeol. 7 (1997) 555-557.

[36] Podborsky V., Praveké Dejiny Moravy, Muzejni a Vlastivedna Spolecnost v Brne, 1993.

[37] Roche J., Nouvelle datation de l'Épipaléolithique marocain, C. R. Acad. Sci. Paris 249 (1959) 729-730.

[38] Roche J., Cadre chronologique de l'Épipaléolithique marocain, in: IX ${ }^{\mathrm{e}}$ Congrès de l'UISPP, Colloque II, université de Nice Press, Nice, France, 1976, pp. 153-157.

[39] Stewart T.D., Stone age skull surgery: a general review with emphasis on the new world, in: Smithsonian Institution Annual Report for 1957 of the Board of Regents, Washington DC, 1958, pp. 469-491.

[40] Thillaud P.L., Paléopathologie des amincissements de la voûte crânienne, L'Anthropologie 87 (1983) 499-519.

[41] Whittle A., Neolithic Europe: a survey, Cambridge University Press, 1985 